\section{Humor er halve vitsen}

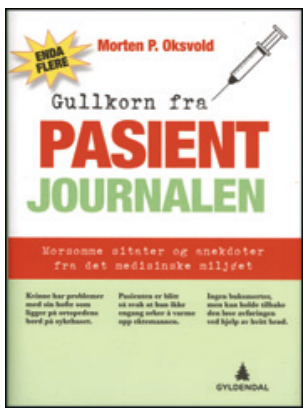

Morten P. Oksvold

Enda flere gullkorn fra pasientjournalen

153 s, ill. Oslo: Gyldendal, 2012. Pris NOK 179 ISBN 978-82-05-42479-1

Dette er tredje utgave av den opprinnelige salgssuksessen Gullkorn fra pasientjournalen (2008), med oppfølgeren Flere gullkorn fra pasientjournalen (2010), som nå er blitt Enda flere gullkorn fra pasientjournalen. Vanligvis er originalen bedre enn oppfølgeren, og for denne leseren synes også det å gjelde her. Likevel, bredden i poengene er dekkende for de fleste smaksløker: fra galgenhumor til sorte spøker, sarkasme og selvironi, til tørre poeng og bløte vitser. Gullkornene sitter ikke like tett som i foregående utgaver, men treffer hyppigst i den siste halvdelen som nettopp dreier seg om utklipp fra pasientjournalen. Første halvdel er delt inn i Medisinske anekdoter, Fra media og Mellom lege og pasient, og er av mer varierende kvalitet, selv om sistnevnte skal være autentiske historier. Noen historier var sikkert mest morsomst «da det skjedde», og mister noe av sin snert i ettertid.

Humor er et ekstremt kraftig virkemiddel (1), og temaer innen psykiatri, demens og underliv skårer ofte billige poeng, men må gjenfortelles med omhu og valg av publikum for ikke å være direkte støtende. Men humor kan også være brobyggende, forløsende og avskrekkende - noe av hele vitsen med å bruke humor i hverdagen, også i helsevesenet.

Boken har samme format som tidligere, dvs. et hendig lommeformat. Den er skrevet på grovt, ubleket papir, med mye tomrom og mellomstore skrifttyper, og fonttypen er av «gammel skrivemaskin»-utseende. Om dette skal henvise til journalnotater fra preelektroniske tider, vites ikke, men dagens nye taleteknologi tyder på at det vil forekomme et like solid (om ikke større) grunnlag for videre journalblundere av denne typen i årene som kommer (2). De fleste poengene er uansett basert på grammatiske blundere, bruk av feil begrep og blanding av uttrykk, i tillegg til innskutte leddsetninger og springende temaer i dikteringen.

Problemet her er universelt og godt dokumentert i barnelegen Howard Bennetts samling fra det engelske språkrom (3), og gir mang en latterkrampe. Slike feil kan imidlertid også være potensielt farlige om de relateres til doseringer, valg av behandling («en» eller «ingen») eller på andre måter hindrer korrekt kommunikasjon. Det er ikke alltid at pekefingeren er beste middel for å skjerpe forsamlingen, og kanskje humoren her kan brukes til å minne oss på hvor fort det kan gå galt i en travel hverdag. Ettersom sans for humor er like mangfoldig som folk flest, vil alle finne noe å humre eller skratte av i Gullkorn: part III.

\section{Kjetil Søreide}

Gastrokirurgisk avdeling

Stavanger universitetssjukehus

\section{Litteratur}

1. Torkelsen PI. Humor e heile vitsen. Oslo: Samlaget, 2012

2. Davidsen C. Legenavn og talegjenkjenning. Tidsskr Nor Legeforen 2013; 133 766. doi: 10.4045/tidsskr.13.0251

3. Søreide K. Lattermildt for leger, om leger, av leger. Tidsskr Nor Lægeforen 2001; 121: 3655

\section{Vart, nært og ærlig}

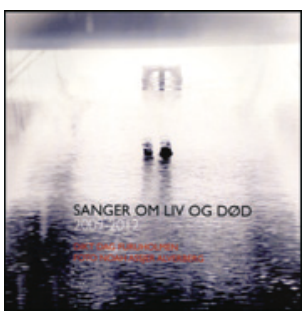

Dag Furuholmen

Sanger om liv og død 2009-2012

Dikt. 100 s, ill. Oslo: Eget forlag, 2012.

ISBN 978-82-998319-1-8

Det første som slo meg da jeg leste Sanger om liv og død av psykiater Dag Furuholmen, var at vi må bli flinkere til å stille spørsmål det ikke finnes svar på. Dag Furuholmen gjør det. Han skriver varmt, nært og søkende om livet selv, preget av at han selv har en alvorlig kreftdiagnose.

Til grunn for Dag Furuholmens sanger ligger en uforbeholden respekt for det dypt menneskelige i alle dets fasetter. Flere av diktene berører menneskets lengsel etter kjærlighet og akseptasjon, hvor grunnlaget legges i barndommen. Diktene spenner fra fortvilelse, sorg, glede, håp og akseptasjon.

Når jeg nå er inne i min siste fase som yrkesaktiv lege, og de siste ti årene har vært veileder for unge turnuskandidater, blir jeg mer og mer klar over hvor faktabasert vår medisinske utdanning og tradisjon er blitt.

Turnuslegene jeg har fått til «finsliping», har vært proppfulle av teoretiske kunnskaper. De har en klokketro på laboratoriesvar og de svarene avanserte undersøkelser gir dem. Jeg ser jo at bare i min tid som praktiserende lege har det diagnostiske verktøyet gjort oss i stand til å stille mye mer presise og riktige diagnoser.

Dag Furuholmen minner oss om at livet består av mer enn presise diagnoser. Han minner oss om betydningen av det helhetlige møtet med pasienten.

Og det er her Sanger om liv og død nærmest forsvarer en plass som pensumbok i medisinstudiet. Den minner oss om at det er det hele mennesket vi skal møte, med ånd, sjel og legeme, som jeg lærte i KFUM. Denne kombinasjonen av dagbok og diktsamling skrevet av en medisiner med innsideerfaring fra det vi hanskes med til daglig - liv og død, usikkerhet og tvil - er det vel verdt å bruke tid på. Forfatteren gir oss både i forordet og i kommentarer en del «anamnestiske» opplysninger, som er med på å lede tankene våre og danne bilder etter hvert som vi leser diktene.

Dette er ikke en bok man setter seg ned og leser fra perm til perm. Diktene er frie i formen med mulighet til egne fortolkninger. De illustrative bildene er alle i svart-hvitt, noen nærmest nonfigurative, og de forsterker denne effekten. Derfor kan det være nok å lese noen sider, ja kanskje bare ett dikt, om gangen.

Diktsamlingen er et vakkert supplement til andre kollegers bøker innen denne sjangeren, f.eks. Stein Husebøs Sykdom, sorg og kjarlighet (2005).

\section{Gunnar Bjerknes-Haugen}

Heer Legekontor 